\title{
RHENIUM-OSMIUM ISOTOPE SYSTEMATICS IN SOUTHERN AFRICAN AND SIBERIAN PERIDOTITE XENOLITHS AND THE EVOLUTION OF SUBCONTINENTAL LITHOSPHERIC MANTLE.
}

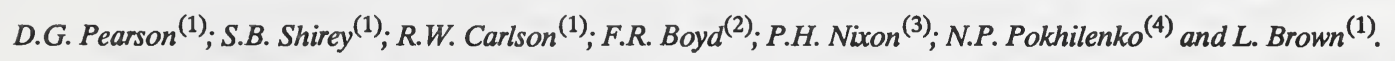

(1) Department of Terrestrial Magnetism, Carnegie Institution of Washington, 5241 Broad Branch Rd N.W., Washington, D.C. 20015; 2) Geophysical Laboratory, Carnegie Institution of Washington, 5251 Broad Branch Rd N.W. Washington, DC 20015; (3) Dept. Earth Sciences, Leeds University, U.K. (4) Institute of Geology \& Geophysics, Siberian Branch, USSR Academy of Sciences, Novosibirsk, USSR.

The Re/Os isotope system provides a powerful tool for constraining models for the formation of cratonic mantle "roots" by relating $\mathrm{Re} / \mathrm{Os}$ model depletion ages in peridotitic mantle residues to chemical changes resulting from basaltic/komatiitic melt extraction and temperature/pressure estimates from mineral thermobarometry. High os concentrations in the xenoliths relative to the host kimberlite magma means that the $R e-O s$ system is much less susceptible to the effects of xenolith infiltration by the kimberlite (Walker et al., 1989). The Siberian and Kaapval cratons both have roots extending into the diamond stability field and contain crustal rocks over $3.5 \mathrm{Ga}$ old. The abundant kimberlites erupted through these cratons frequently entrain xenoliths from varying depth allowing analysis of rocks from the whole lithospheric section. Osmium isotope ratios in whole rock peridotite xenoliths of various lithologies have been determined by the N-TIMS (negative thermal ionization mass spectrometry) technique.

Peridotite xenoliths from the lithosphere beneath the Archean Kaapvaal craton analysed in this study and data from the study by Walker et al. (1989) show a range of 187 os/1860s from 0.880 to 1.070 . Many of these xenoliths have extremely unradiogenic 1870 s/1860s compared to xenoliths from alkaline magmas intruding Proterozoic lithosphere, 1.002 to 1.095 ( $R$. Walker, unpublished data), and dredged oceanic abyssal peridotites, 1.003 to 1.099 (Martin in press; Fig. 1). The distinct os isotope characteristics of peridotite xenoliths from Archean cratons indicate the peridotites have resided in the ancient lithospheric "root" to the craton for very long time periods ( $>2 \mathrm{Ga})$, where they have been chemically and physically isolated from the convecting asthenosphere.

Os concentrations in the Kaapvaal xenoliths range from 1.47 to $9.60 \mathrm{ppb}$ and $187 \mathrm{Os} / 186 \mathrm{Os}$ is negatively correlated with degree of major element depletion (eg. mg\# of olivine). A low-Ca garnet harzburgite, PHN2825 (mg\# 0.96), from Liqhobong, S.E.Kaapvaal margin, gives a 187 os/186os of $0.880 \pm 0.002$ and a minimum Re-Os model depletion age ( $\mathrm{T}_{\mathrm{RD}}$ ) of $3.3 \mathrm{Ga}$ (Fig.1) assuming the rock lost all its $\mathrm{Re}$ at this time. Incomplete removal of $\mathrm{Re}$ during melting would lead to a higher model age. The $3.3 \mathrm{Ga} \mathrm{Re}$ depletion age for PHN2825 is significant in that low Ca-garnet harzburgites are thought to be one of the dominant source lithologies for P-Type diamonds (eg. Nixon et al., 1987) and the $\mathrm{Re}$ depletion age is within error of the $\mathrm{Sm} / \mathrm{Nd}$ model ages determined by Richardson et al (1984) on garnet inclusions in diamond. A coarse garnet harzburgite, also from liqhobong, has a $1870 \mathrm{~s} / 186 \mathrm{O}$ of $0.915 \pm 0.001$ and a minimum Re-Os model age of 2.8 $\mathrm{Ga}$. These ages are comparable to a $2.8 \mathrm{Ga}$ Re-Os model age 
obtained by Walker et al. (1989) from a Letseng peridotite, also near the S.E. margin of the craton, and indicate ancient stabilization of the margins of the sub-continental Kaapvaal lithosphere.

The lowest Os abundance in the suite occurs in the ultradepleted low Ca-garnet harzburgite. Although Os is a compatible element in mantle residues at moderate amounts of melting, high degrees of melting ( $>30 \%)$, perhaps associated with komatiite extraction, may result in the break down of Os hosting phases in the residue, eg. sulphides or native metals and hence cause low Os abundances in ultra-depleted residues such as low Ca-garnet harzburgites

Two spinel facies peridotites of shallow origin, from the Premier pipe, have $187 \mathrm{Os} / 186 \mathrm{Os}$ of $0.940 \pm 0.003$ and $0.962 \pm 0.005$, yielding Proterozoic minimum Re-Os model ages (Fig. 1). Proterozoic Re-Os model ages were also obtained from high temperature garnet peridotites from Premier by Walker et al. (1989). This result is surprising in that the Premier kimberlite intrudes a more central area of the craton compared to the $\mathrm{N}$. Lesotho pipes and therefore may be expected to be older. The present data set shows no geographical correlation with Re depletion age of the lithosphere and no apparent correlation between depletion age and depth of equilibration in the lithospheric mantle as determined by mineral thermobarometry. These findings may indicate significant age heterogeneity in the nuclei that accrete to form cratonic lithosphere but further detailed investigation is required of depth/age relationships of xenoliths from individual pipes.

\section{References}

Martin, C.E. (in press) Osmium isotopic characteristics of mantle derived racks. Geochimica et Cosmochimica Acta, vol 55.

Nixon, P.H., van Calsteren, P.W.C, Boyd, F.R. and Hawkesworth, C.J. (1987) Harzburgites with garnets of diamond facies from southern African kimberlites. In P.H. Nixon, Ed., Mantle Xenoliths, 523-533, Wiley, New York.

Richardson, S.H., Gurney, J.J, Erlank, A.J, and Harris, J.W. (1984) Origin of diamonds in old enriched mantle. Nature, 310, 198-202.

Walker, R.J., Carlson, R.W., Shirey, S.B. and Boyd, F.R. (1989) Os, $\mathrm{Sr}, \mathrm{Nd}$ and $\mathrm{Pb}$ isotope systematics of southern African peridotite xenoliths: Implications for the chemical evolution of subcontinental mantle. Geochimica et Cosmochimica Acta, 53,15831595. 


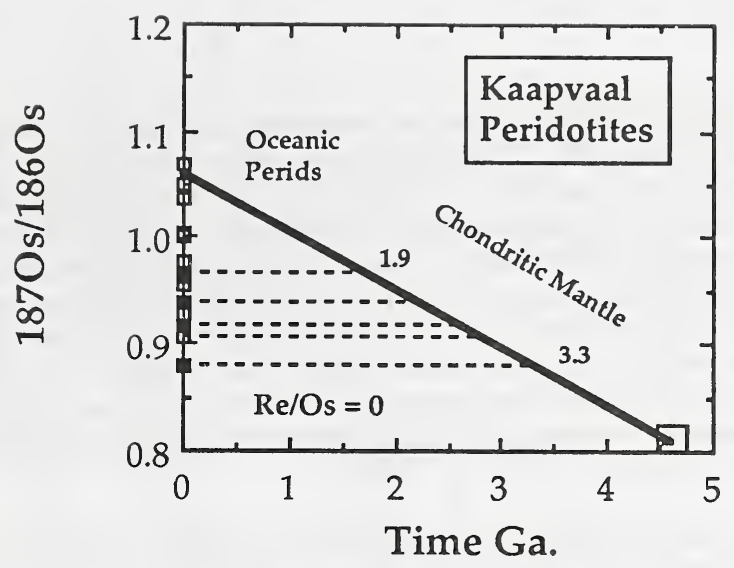

Figure 1. Osmium isotope evolution diagram for Kaapvaal peridotite xenoliths. Present day isotopic compositions are projected back to the Chondritic Mantle Evolution Curve $(187 \mathrm{Re} / 186 \mathrm{Os}=3.3)$ given by walker et al. (1989) assuming a ${ }^{187} \mathrm{Re} / 186 \mathrm{Os}$ of zero to yield minimum Re model depletion ages $\left(\mathrm{T}_{\mathrm{RD}}\right)$; age indicated in $\mathrm{Ga}$. Additional data are Kaapvaal peridotite xenoliths analysed by Walker et al (1989), open squares, and the range for oceanic abyssal peridotites from Martin (in press), shaded region. 